\title{
DESAIN SET CATUR UNTUK ANAK-ANAK DENGAN MOTIF BATIK KALIMANTAN TIMUR
}

\author{
Andi Farid Hidayanto \\ Staf Pengajar Program Studi Desain Produk, Jurusan Desain \\ Politeknik Negeri Samarinda \\ e-mail: andifarid@polnes.ac.id \\ Muhammad Wahyudi \\ Mahasiswa Program Studi Desain Produk, Jurusan Desain \\ Politeknik Negeri Samarinda
}

\begin{abstract}
ABSTRAK
Perancangan dan pengembangan produk set catur menjadi suatu bagian dari pengembangan desain. Namun set catur yang ada saat ini kurang bervariasi. Umumnya set catur yang ada ialah hanya berbentuk kerajaan dan memiliki warna hitam dan putih tanpa adanya pengenalan budaya indonesia khususnya batik Kalimantan Timur. Set catur yang ada saat ini juga jarang sekali memiliki tempat penyimpanan yang baik sehingga tempat penyimpanan bidak catur tidak tersusun rapi pada saat permainan selesai. Dengan adanya hal tersebut maka seorang desainer berusaha menciptakan suatu barang yang lebih baik dengan inovasi yang baru. Seperti merancang sebuah set catur yang mudah dimengerti oleh anak-anak, merancang sebuah set catur yang dapat mengenalkan budaya batik Kalimantan Timur khususnya batik Dayak Kenyah, dan merancang set catur yang mempunyai nilai estetis. Dalam desain produk ini memberi alternatif baru dalam pengembangan desain mebel khususnya set catur. Dengan metode perancangan yang sudah dilakukan antaranya: preliminary design, design development dan final design. Sehingga dihasilkan desain set catur untuk anak-anak yang memiliki gaya desain modern minimalis.
\end{abstract}

Kata Kunci : Set, Catur, Anak-Anak, Motif, Batik, Kalimantan, Timur

\begin{abstract}
The design and development of chess set products into a part of the development of design in the business world, especially children's games. But the current chess sets are less varied. Generally chess set that there is only a royal and has a black and white color without any introduction of Indonesian culture, especially batik East Kalimantan. The current chess set also rarely has good storage so chess storage is not neatly arranged when the game is over. With this in mind, a designer tries to create a better item with new innovations. Like designing a chess set that is easily understood by children, designing a chess set that can introduce East Kalimantan batik culture especially Dayak Kenyah batik, and designing chess sets that have aesthetic value. In this report with the title "Set chess for children with batik motif east kalimantan" gives a new alternative in the development of furniture design especially chess sets. With the design methods that have been done include: data collection analysis, design alterrnatif, design development of selected alternatives, and final design. So produced chess set design for children who have a modern minimalist design style.

Keywords: Set, Chess, For, Children, Motif, Batik, East, Borneo 52
\end{abstract}


Vol. 5, No. 2, April 2018

\section{PENDAHULUAN}

Catur adalah permainan yang membutuhkan proses dan pemikiran sehingga akan membutuhkan waktu yang cukup lama untuk menyelesaikan satu permainan. $\mathrm{Ca}$ tur pada dasarnya bisa membuat anak untuk berpikir secara strategi sehingga bisa memenangkan beberapa langkah ke depan. Keterampilan untuk membentuk strategi serta pemecahan masalah anak pun akan semakin meningkat. Anak-anak belajar untuk melihat masalah dari berbagai sudut ketika memainkan permainan dan menemukan solusi untuk masalah ini. Permainan catur ini sangat bermanfaat untuk anak-anak. Contohnya memperkuat ingatan, karena dengan bermain catur anak-anak memiliki memori yang kuat.

Namun set catur yang ada saat ini kurang bervariasi. Umumnya set catur yang ada berbentuk kerajaan dan memiliki warna hitam dan putih tanpa adanya pengenalan budaya indonesia khususnya batik Kalimantan Timur. Dilihat dari masalah yang muncul pada produk maka diberikan inovasi dengan mengubah, membuat atau memperbaiki produk dari existing yang ada menjadi produk yang fungsional dan menarik sehingga memiliki nilai jual yang lebih dan mampu mengundang produsen untuk menggunakan produk tersebut. salah satu produk set catur yang akan di inovasikan yaitu membuat set catur yang memiliki bentuk dan warna yang sesuai untuk anak-anak. Dan mengenalkan budaya indonesia khusunya batik Kalimantan agar anak dapat mengembangkan karakter dan dapat mengasah otak sambil belajar.

\section{METODE DESAIN}

Dalam mendesain produk agar terarah langkah-langkahnya menggunakan metode Vinot Goel (1981), dengan tahapan-tahapan sebagai berikut:

\subsection{Preliminery Design}

Berupa Pengumpulan data dan informasi, selanjutnya dianalisis berdasarkan konsep desain makro meliputi 1). Perumusan mas- alah, 2). Tinjauan Pustaka, 3). Analisis dan Spesifikasi Desain, dan hasil dari tahap ini akan 4). Spesifik Desain

\subsection{Design Development}

Pada tahap ini dibuat alternatif gambar komponen serta rancangan secara wire diagram dengan bentuk 3D (tiga dimensi) meliputi 1). Desain Alternatif, 2). Pengembangan Desain Alternatif Terpilih

\subsection{Final Design dan Prototype}

Berupa desain akhir, dibuat gambar-gambar meliputi gambar presentasi 3D dan gambar teknik, selanjutnya adalah pembuatan komponen-komponen dilakukan assembling (exploded) atau perakitan sehingga menjadi produk (prototype).

\section{PEMBAHASAN \\ 3.1. Analisa aktifitas}

Analisis aktifitas dan kebutuhan dilakukan untuk mengetahui aktivitas yang dilakukan berkaitan dengan produk yang akan dibuat sehingga diperoleh data kebutuhan pengguna. Berdasarkan kebutuhan tersebut maka dibuat pemecahan fasilitas untuk memenuhi kebutuhan yang dapat diaplikasikan pada produk. Dari analisis aktifitas saat bermain catur, didapat kebutuhan data sebgai berikut:

1. Membuka papan catur.

Kebutuhan untuk aktifitas ini adalah suatu papan catur dengan sistem kuncian yang menggunakan material kuncian pengait untuk membuka dan menutup papan catur.

2. Mengambil bidak catur.

Kebutuhan untuk aktifitas ini adalah suatu tempat penyimpanan bidak catur yang tersusun rapi agar memudahkan pengguna untuk mengambil bidak catur.

3. Menyusun bidak catur.

Kebutuhan aktifitas ini adalah meyusun bidak catur di papan catur yang sudah disediakan tempatnya dipapan catur. 
Andi Farid Hidayanto, Muhammad Wahyudi, Desain Set Catur Untuk Anak-anak Dengan Motif Batik Kalimantan Timur

4. Bermain catur.

Kebutuhan untuk aktifitas ini adalah bermain catur di papan catur yang ada disediakan.

5. Menyusun kembali bidak catur.

Kebutuhan untuk aktifitas ini adalah perlu adanya handle untuk mambawa papan catur pada saat selesai bermain.

\subsection{Analisa ergonomi}

Data ergonomi diperlukan untuk membuat produk. Begitu juga dengan produk set catur untuk anak-anak. Ergonomi berarti aturan yang berkaitan dengan kegiatan bermain. Sasaran penelitian ergonomi adalah manusia pada saat bermain dalam lingkungannya, secara singkat dapat dikatakan bahwa ergonomi ialah penyesuaian tugas pekerjaan dengan kondisi tubuh manusia dengan sehari-hari yang akan dihadapi, yaitu dengan cara menyesuaikan ukuran area permainan dengan dimensi tubuh agar tidak melelahkan. Analisis ergonomi dilakukan untuk meminimalkan resiko kesehatan dan keselamatan. Dan juga agar kenyamanan dalam melakukan kegiatan menggunakan produk dapat maksimal, ergonomi sangat diperlukan untuk membuat produk. Aktifitas yang dianalisis membutuhkan fasilitas-fasilitas yang dapat digunakan pada saat bermain seperti bermain catur dan menyusun bidak catur dengan rapi.
Antropometri yang digunakan untuk menentukan dimensi lebar tangan untuk handle papan catur yaitu lebar telapak tangan terhadap lebar handle adalah kelompok rata-rata pria $50 \%$ tile, sehingga ukuran yang diperoleh tersebut adalah $70 \mathrm{~mm}$ alasan digunakannya antropometri ini adalah agar anak merasa nyaman saat mengangkat papan catur menggunakan handle.

Antropomentri yang digunakan untuk menentukan demensi tinggi papan catur adalah panjang kelompok rata- rata pria $50 \%$ tile, sehingga ukuran yang diperoleh tersebut adalah $130 \mathrm{~mm}$, alasan digunakannya antropometri ini adalah agar anak merasa nyaman saat memegang papan catur.

Antropometri yang digunakan untuk menentukan bidak catur adalah dimensi antropometri genggaman tangan pada posisi memegang bidak catur. Gender yang digunakan adalah pria. Jenis antropometri yang digunakan unuk kelompok wania 50\% tile, yaitu $70 \mathrm{~mm}$.

\subsection{Analisis Konfigurasi}

Analisis konfigurasi dilakukan untuk mendapatkan susunan atau konfigurasi dari tiap-tiap komponen yang terdapat pada set catur. Dari beberapa konfigurasi yang ada setelah dilakukan analisis terpilih konfigurtasi seperti yang ditunjukkan dalam gambar 1.

\section{Tampak Dalam}
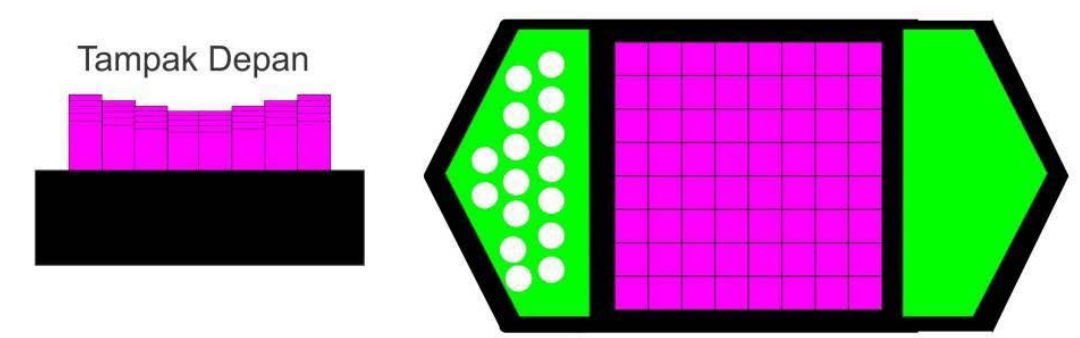

Tampak Atas
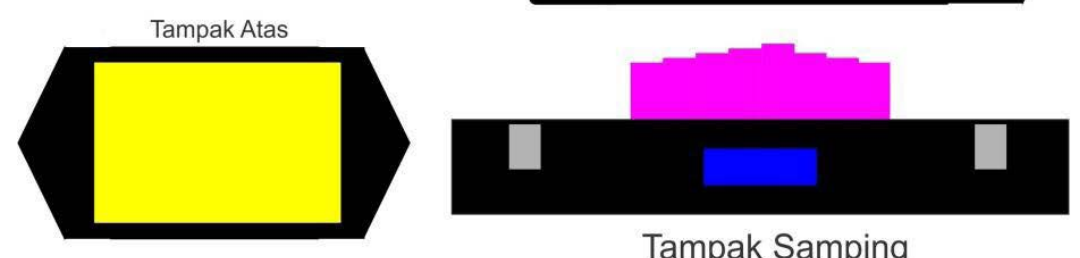

Keterangan :

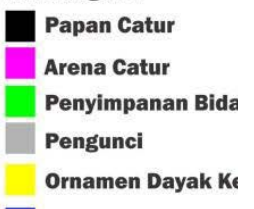

Gambar 1. Analisis Konfigurasi terpilih 
Vol. 5, No. 2, April 2018

Pada alternatif konfigurasi pada gambar 1, penempatan arena catur dan tempat penyimpanan lebih efisien karena pada saat bermain, tangan tidak terlalu jauh menjangkau ke depan dan lebih mudah mengambil anak catur, serta bentuk arena raja berbeda dengan yang lain karena raja lebih istimewa. Pada bagian pengunci penempatan nya berada disamping agar kuncian lebih rapat.

\subsection{Analisis Sistem}

Analisis sistem perlu dilakukan untuk mengetahui sistem-sistem apa saja yang diperlukan pada produk agar dapat berfungsi secara benar tanpa mengurangi kenyamanan produk. Berikut sistem-sistem yang digunakan pada produk.

1. Sistem Sambungan

Berdasarkan hasil analisis dari beberapa sambungan yang telah dilakukan maka sambungan yang sesuai untuk diaplikasikan pada produk adalah sambungan sekrup, karena tahan lama kuat dan kokoh.

2. Pembuatan anak catur

Anak catur digunakan untuk memainkan dan memenangkan permainan. Dalam pembuatan set catur ini khususnya anak catur ada beberapa jenis pembuatan yang dapat diaplikasikan. Berdasarkan hasil analisis proses pembuatan anak catur yang telah dilakukan, yang sesuai untuk diaplikasikan pada produk adalah sistem pahat ukir. Karena sistem ini mudah dibentuk sesuai keinginan dan tidak membutuhkan waktu yang lama pada saat pengerjaan.

3. Finishing Papan Catur

Berdasarkar hasil analisis dari beberapa finishing papan catur yang telah dilakukan maka finishing yang diaplikasikan pada produk adalah finishing dengan menggunakan cat deco, karena cat deco fleksibel, memiliki banyak varian warna dan hasilnya terlihat fancy.

4. Finishing Bidak Catur

Berdasarkan hasil analisis finishing untuk bidak catur yang telah dilakukan, didapatkan finishing yang sesuai untuk diaplikasikan pada produk adalah finishing dengan menggunakan cat akrilik, karena cat akrilik mudah kering dan, memiliki banyak varian warna dan hasilnya yang terlihat fancy.

\section{Kuncian}

Berdasarkan hasil dari analisis sistem kuncian yang telah dilakukan, maka sistem kuncian yang sesuai untuk diaplikasikan pada produk adalah sistem pengait. Karena sistem ini memiliki pengait yang baik dan mudah untuk digunakan pada saat membuka penutup papan catur.

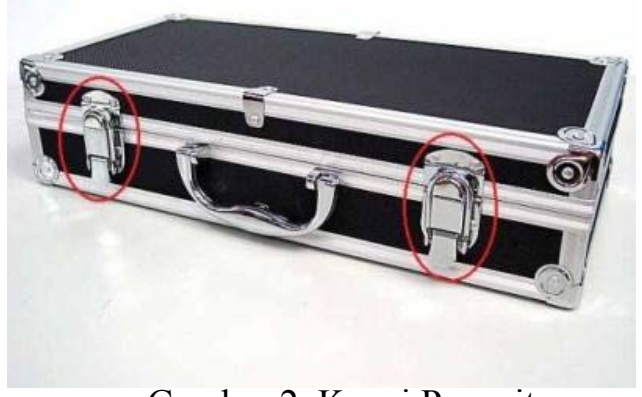

Gambar 2. Kunci Pengait

\subsection{Analisis Material}

Dari hasil analisis material yang telah dilakukan, dipilih material kayu jenis multiplek/triplek, menjadi material utama untuk membuat papan catur. Untuk anak catur digunakan kayu pinus.

\subsection{Analisis Bentuk}

Analisis bentuk yang dilakukan untuk menentukan gaya desain apa yang sesuai dengan konsep yang akan diaplikasikan pada set catur anak-anak dengan tema batik Kalimantan ini. Analisis pada set catur untuk anak-anak selain menentukan dari segi bentuk dan material di satu sisi terdapat usaha dari pemerintah untuk mengekspos kembali budaya motif Batik Kalimantan khususnya Kalimantan Timur, sehingga untuk set catur 
Andi Farid Hidayanto, Muhammad Wahyudi, Desain Set Catur Untuk Anak-anak Dengan Motif Batik Kalimantan Timur

diberikan motif batik dayak kenyah untuk mengembangkan program pemerintah daerah.

Batik yang diaplikasikan ke produk yaitu batik dayak kenyah, sedangkan untuk papan catur memakai gaya desain Minimalis, dengan menyederhanakan bentuk, tanpa merubah bentuk aslinnya. Yaitu, dengan memberikan sedikit outline.

\subsection{Analisis Warna}

Analisis warna yang dilakukan guna menentukan warna yang akan diterapkan pada produk. Analisis warna dilakukan dalam dua jenis, yaitu untuk warna yang mendominasi dan untuk warna yang digunakan sebagai aksen. Dari hasil analisis yang telah dilakukan, Warna-warna yang digunakan adalah warna-warna pada batik dayak kenyah. karena untuk memperkenalkan budaya Dayak kepada anak-anak. Warna yang digunakan yaitu warna merah, kuning, dan hitam karena warna ini akan diaplikasikan ke set catur. Warna merah dan kuning menjadi warna dominan karena warna tersebut adalah warna cerah karena warna tersebut adalah warna primer, diaplikasikan dibagian kotak-kotak papan catur dan pada bagian bawah anak catur. Warna hitam akan diaplikasikan ke anak catur pada bagian atas anak catur sebagai penetralisir dari warnawarna cerah tersebut. Warna hitam memiliki sifat netral dimana warna ini sangat cocok untuk anak untuk membangun dunianya sendiri.

\subsection{Analisis desain awal}

Desain awal digunakan untuk memberi gambaran bentuk produk. Desain awal ini terdiri dari beberapa alternatif desain. Selanjutnya alternatif-alternatif desain tadi dianalisis kelebihan dan kekurangannya disesuaikan dengan konsep ptoduk dengan berbagai pertimbangan. Dari beberapa alternatif desain, terpilih alternatif desain seperti yang ditunjukkan gambar 3 .

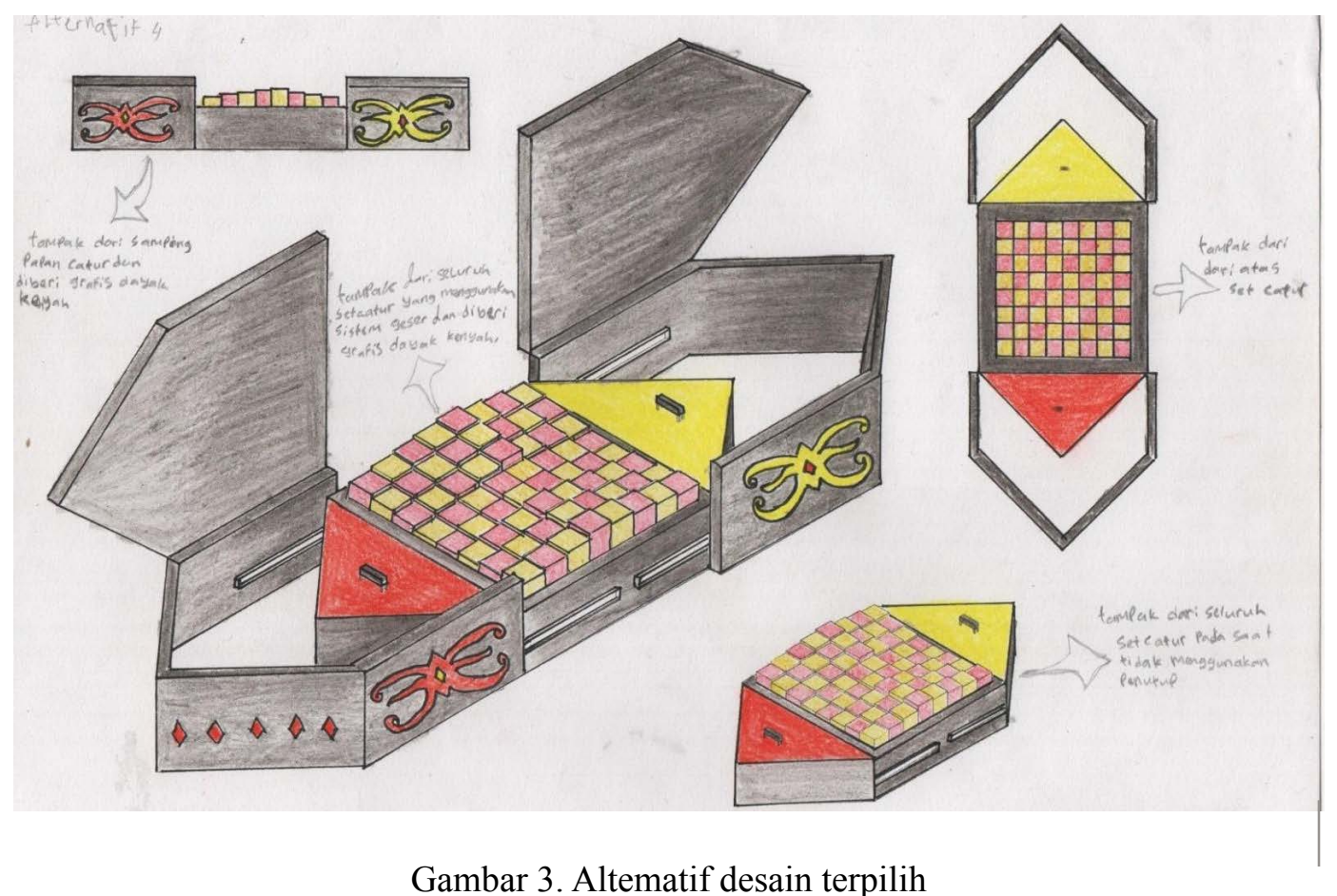

Gambar 3. Altematif desain terpilih 
Vol. 5, No. 2, April 2018

Pada desain alternatif dalam gambar 3, produk mudah diproduksi dan memiliki grafis pada bagian samping agar terlihat menarik. Pada bagian penutup langsung menyatu dengan papan catur agar tidak merepotkan pengguna pada saat menggunakan set catur. Namun kekurangan dari alternatif ini ialah memiliki lebih banyak komponen dan banyak membuang bahan dan memiliki ruang kosong pada bagian tengah catur. System dalam alternatif desain ini memudahkan pengguna pada saat mengambil dan menggeser kembali papan catur tanpa harus mengangkat penutup.

\subsection{Desain Pengembangan}

Desain alternatif terpilih tadi selanjutnya dikembangkan menjadi dalam berbagai alternatif desain pengembangan. Dalam pengembangan sudah dikondisikan produk bisa diproduksi maasal untuk dipasarkan, sehingga unsur-unsur produksi menjadi pertimbangan. Dari beberapa alternatif pengembangan, setelah dilakukan analisis terpilih alternatif pengembangan desain seperti yang ditunjukkan dalam gambar 4 dan gambar 5 .

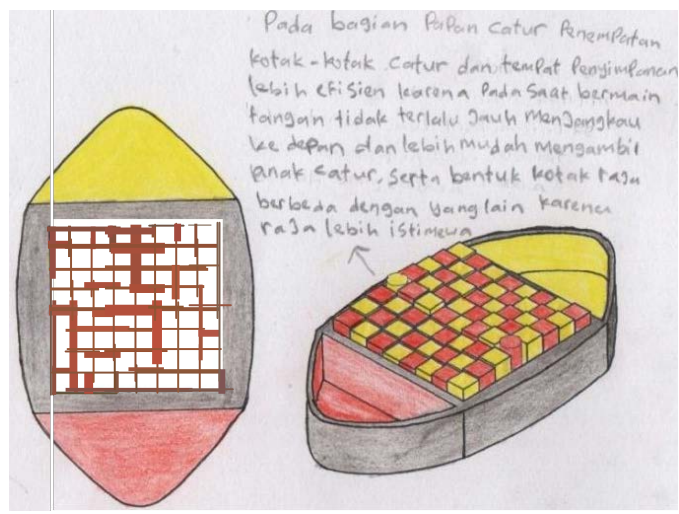

Gambar 4. Pengembangan desain terpilih

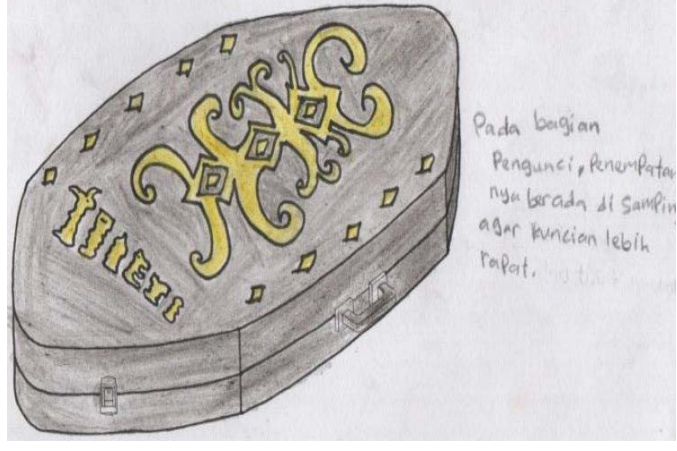

Gambar 5 Pengembangan desain terpilih

\subsection{Final Desain}

Gambar pengembangan desain terpilih tadi selanjutnya disempurnakan menjadi desain final. Desain final ini meliputi gambar presentasi, gambar teknik, gambar modelling, dan spesifikasi teknik. Selanjutnya dibuat prototipe produknya, untuk dianalisis guna dilanjutkan ke dalam tahap produksi, agar bisa diproduksi masaal untuk dipasarkan ke mayasrakat. 


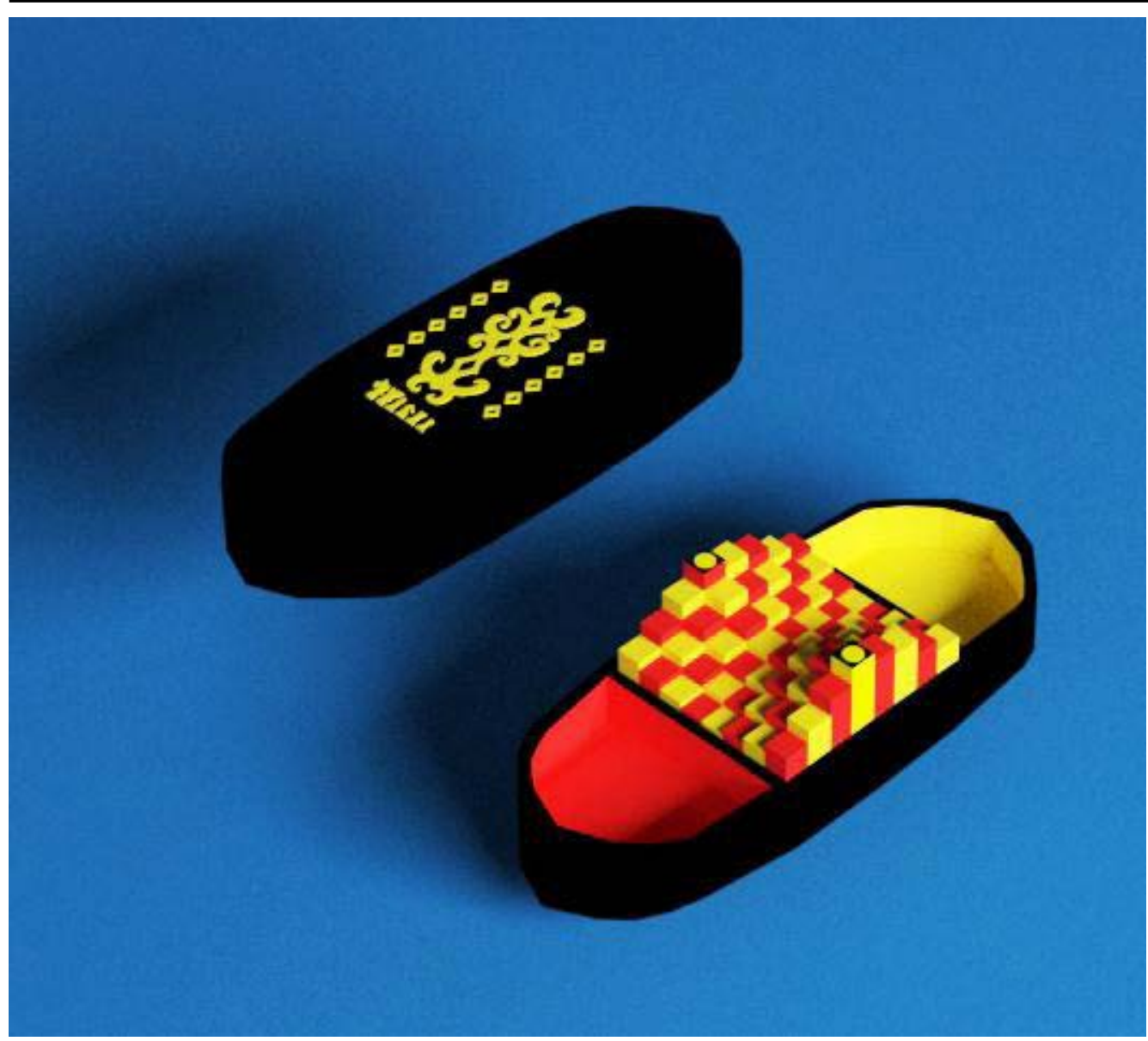

Gambar 6. Final Desain

\section{KESIMPULAN DAN SARAN}

Kesimpulan dari hasil perancangan "Set Catur Untuk Anak-Anak Dengan Tema Batik Kalimantan" ialah sebagai berikut: Proses desain merancang sebuah set catur yang pangsa pasarnya adalah anak-anak. Desain set catur ini menggunakan motif batik dayak kenyah Kalimantan Timur, juga untuk memperkenalkan budaya sebagai salah satu program pemerintah daerah.

Untuk hasil yang lebih baik, ke depannya set catur ini masih dapat dikembangkan menjadi lebih baik dari sistem, bentuk maupun warna yang digunakan untuk menyelesaikan produk ini agar mendapat nilai tambah. 
Vol. 5, No. 2, April 2018

DAFTAR PUSTAKA

Akmal, Imelda, Dkk, (2013). Kayu Olahan. Jakarta, PT. Gramedia https://books.google. co.id 7 Desember 2017.

Allen, Edward. (2002). Dasar-Dasar Konstruksi Bangunan. Jakarta, Penerbit Erlangga. https://books.google.co.id 30 November 2017.

Cahyadi, Dwi. (2014). Aplikasi Mannaquin Pro Untuk Desain Produk, Yogyakarta; LeutikaPrio. 29 November 2017.

Utara, PT.Prenhallindo. https://books.google.co.id 26 November 2017. Magethi, Bey. (2009). Pedoman bermain catur. Bandung : Pionir Jaya.

Murtono, Sri, Dkk, (2007). Seni Budaya Dan Keterampilan. Jakarta Timur, Yudhistira. https://books.google.co.id 19 Desember 2017.

Sulastianto, Harry, Dkk, (2007). Seni Budaya Untuk SMA Kelas X. Bandung, Grafindo 